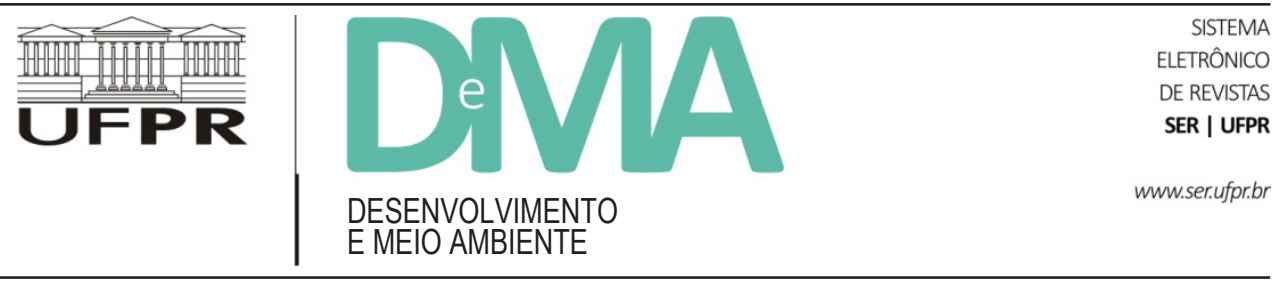

\title{
Marine Spatial Planning in Asia and the Caribbean: Application and Implications for Fisheries and Marine Resource Management
}

\section{Planejamento Espacial Marinho na Ásia e no Caribe: aplicações e implicações para a gestão das pescarias e dos recursos marinhos}

\author{
Robert S. POMEROY ${ }^{*}$, Kimberly BALDWIN², Patrick McCONNEY² \\ ${ }^{1}$ University of Connecticut-Avery Point, Groton, United States. \\ ${ }^{2}$ Centre for Resource Management and Environmental Studies (CERMES), University of the West Indies, Cave Hill, Barbados. \\ *E-mail of contact: robert.pomeroy@uconn.edu
}

Article received in March 9, 2014, final version accepted in September 2, 2014.

ABSTRACT Marine spatial planning (MSP) has emerged as a highly promoted approach to implementing integrated management of coastal and ocean areas. It is linked to ecosystem-based management (EBM), the ecosystem approach to fisheries (EAF), geographic information systems (GIS), marine protected areas (MPAs) and more. Although MSP has gained global attention, its use appears to be less prominent in small island developing states (SIDS) and other developing countries than in developed countries. The purpose of this paper is to discuss the implications and practical application of MSP as an ocean resource management paradigm in Asia and the Caribbean. Where will MSP fit in the range of management paradigms? Where and how can it be best utilized for integrated resource management? What are challenges for implementation? Examples of use of MSP and marine zoning are presented and discussed.

Keywords: Asia; Caribbean; marine spatial planning.

RESUMO O Planejamento Espacial Marinho (MSP) surgiu como uma abordagem fortemente promovida para implementar a gestão integrada das áreas costeiras e marinhas. Está relacionado à gestão baseada no ecossistema (EBM), à abordagem ecossistêmica para as pescarias (EAF), aos sistemas geográficos de informação (GIS), às áreas marinhas protegidas (MPAs), entre outros. Embora o MSP tenha recebido atenção em nível global, seu uso parece ser menos proeminente nos Estados-ilha em desenvolvimento (SIDS) e outros países em desenvolvimento, se comparado ao seu uso nos países desenvolvidos. O objetivo deste artigo é discutir as implicações e as aplicações práticas do MSP enquanto um paradigma para a gestão dos recursos marinhos na Ásia e no Caribe. De que forma o MSP se ajusta à gama de paradigmas de gestão existentes? Onde e como ele pode ser melhor utilizado para a gestão integrada dos recursos? Quais são os desafios para a sua implementação? São apresentados e discutidos alguns exemplos de uso do MSP e do zoneamento marinho.

Palavras-chave: Ásia; Caribe; planejamento espacial marinho. 


\section{Introduction}

The oceans of the world are both critical for economic and food security and as a global conservation priority. Over the past decades, the demand for ocean space for multiple uses has increased greatly through expansion of traditional uses (i.e. fisheries, marine transportation) and new uses (i.e. energy development, aquaculture). The ecological transition facing the world's ocean resources as a result of overfishing and degradation of ecosystems is happening rapidly, and the effects are far-reaching. The resources; the people who use and consume them; production practices; management institutions; the environment that supports them; and the local, national and international legal instruments governing their ownership and use will all be affected. The transition in ocean uses and regimes is especially apparent in small island developing states (SIDS) in the Caribbean and larger developing countries in Asia. In these countries, low-income people will be hardest hit when their fragile purchasing power and often tenuous access to the resources upon which they depend for food and livelihoods are further challenged (WorldFish Center, 2011).

Competition and conflict for space and resources characterizes the oceans of both the Asia and Caribbean regions (CEMARE, 2002; Pomeroy et al., 2007; Pomeroy, 2011). Because of some of the highest rates of population growth and increasing food and development needs in Asia, marine areas are now experiencing increased levels of conflict and social unrest as a result of differing and uneven levels of economic development, resource use, and technological change between urban and rural area within a country. Economic and technological changes in the last 15 years have caused serious discrepancies in access to ocean resources in the region.

In the Caribbean the pressures are different and at different spatial and jurisdictional scales, but equally distressing. Marine space uses and abuses from fisheries, tourism, aquaculture, energy and land-based sources of pollution interact in complex ways with each other as well as natural disasters, climate change and climate variability (Fanning et al., 2011). Social-ecological system (SES) variability in local to transboundary marine resources and resource uses, combined with the close proximity of nation-states to each other, makes the Caribbean one of the most complex marine areas in the world on several scales and levels (Mahon et al., 2010), and hence challenging to monitor effectively.

Increased activity in the ocean environment has led to two important types of conflict in the regions: (1) conflicts among human uses (user-user conflicts); and (2) conflicts between human uses and the marine environment (user-environment conflicts such as aquaculture development and mangrove clearing). These conflicts weaken the ability of the ocean to provide the necessary ecosystem services upon which humans and all other life depend.

A number of ocean and coastal management paradigms have been proposed and utilized in these regions through the decades to address this increasing competition and conflict including conventional fisheries management, ecosystem approach to fisheries (EAF), ecosystem approach to fisheries management (EAFM), integrated coastal management (ICM), marine protected areas (MPAs), regional ocean governance, integrated ocean and coastal management, and ecosystem based management (EBM), to name a few (UNEP, 2011). These paradigms have had mixed results, in many cases due to actual single sector management approaches despite the rhetoric of integrated management. Recently a new paradigm has been introduced to influence the location of human activities in space and time: marine spatial planning (MSP). A number of countries within the Asian and Caribbean regions have begun to organize uses of the ocean in order to make them more compatible, or at least to reduce the impact on one another, through use of MSP.

The purpose of this paper is to discuss the implications and practical application of marine spatial planning as an ocean and coastal resource management paradigm in Asia and the Caribbean. Where will MSP fit in the range of management paradigms? How does it fit into small-scale fisheries management? Examples of use of MSP and marine zoning will be presented and discussed with special attention to SES dynamics, monitoring and stewardship. Suggested actions to move MSP forward in both regions are discussed. 


\section{A range of paradigms}

Over the last five decades a range of coastal, fisheries and ocean resources management paradigms have been introduced in the Asia and Caribbean regions. Management approaches have shifted from fisheries sector-specific to ecosystem-based approaches that encompass entire aquatic resource systems, including both natural and human components, or integrated coastal management approaches that include multiple sectors and activities on land as well as in the water. An emphasis on structured participation is evident in recent approaches; for example, in rights-based management, in which certain individuals or groups have exclusive or preferential access to specific fishery resources; community-based management, where the community (not just the resource users) manages its own fisheries; co-management, in which management of a fishery is shared between government and the fishing community; and the sustainable livelihood approach, which puts people, particularly the poor, at the center of development (CRC, 2006; Christie et al., 2007).

Fisheries management has shifted from conventional fisheries management, based on the need for data-intensive, biological assessment of the status of resources and management focused on selected reference points, introduced from the 1960s to 1990s. The trend in this millennium is towards an ecosystem approach to fisheries management (EAFM) or ecosystem approach to fisheries (EAF) based on accounting for effects on other parts of the ecosystem in which a fishery is embedded, recognizing the broader economic and social interests of stakeholders, and accounting to a much larger extent for institutional, political, cultural and social objectives (Pomeroy et al., 2013). EAFM and EAF are similar.

Ecosystem-based management (EBM) was introduced in the 2000s and is defined as an integrated approach to management that considers the entire ecosystem, including humans (UNEP, 2011). The goal of $\mathrm{EBM}$ is to maintain an ecosystem in a healthy, productive and resilient condition so that it can provide the goods and services humans want and need. EBM differs from approaches that usually focus on a single species, sector, activity or concern; it considers the cumulative impacts of different sectors. EBM when applied principally to fisheries management is most commonly referred to as ecosystem-based fisheries management (EBFM) (Christie et al., 2007). The main difference between EBFM and EAFM is that EBFM will only consider the ecological impacts of fishing, whereas EAFM is a broader concept and also considers the impact of the environment on fishing, the impact of fishing on the environment and the socio-economic benefits that can be gained from fishing and post-harvest activities.

Integrated coastal management (ICM) was introduced to the regions in the late 1980s as a process by which rational decisions are made concerning the conservation and sustainable use of coastal resources and space (Cincin-Sain \& Knecht, 1998). The process is designed to overcome the fragmentation inherent in single-sector management approaches, in the splits in jurisdiction among different agencies and levels of government, and in the land-water interface. The ICM concept has been further expanded by Integrated Coastal and Marine Resource Management (ICMRM), introduced in the 2000s, to achieve a set of management and sustainable use goals in coastal and marine habitats that balances economic growth with sustainable resource use by uniting government and community, science and management, sectoral and public interests in preparing and implementing an integrated plan for the management and sustainable development of coastal and marine habitats (Christie, 2005). In addition to ICM and ICMRM, there is integrated watershed management (Heathcote, 2009) and integrated river basin management (World Bank, 2006) that, while focused primarily on freshwater resources, are connected to coastal ecosystems and the sea. Land use and regional planning of terrestrial areas has been utilized in the region since the 1970s. Land use zoning has been used to implement the land use plans. Sustainable Land Management is the term often now used to reflect intergenerational and integrated terrestrial stewardship (World Bank, 2006).

Large marine ecosystems (LMEs) are regions of the world's oceans, encompassing coastal areas from river basins and estuaries to the seaward boundaries of continental shelves and the outer margins of the major ocean current systems (Sherman \& Hempel, 2009). The 
Southeast Asian region has four LMEs, Gulf of Thailand, South China Sea, Sulu-Celebes Sea, and Indonesian Sea, for which there are projects and programs. Regional ocean governance mechanisms, such as regional seas programs, are established by coalitions of national governments to address transboundary ocean and coastal issues (Eagle, 2006). A current example is the Coral Triangle Initiative. Seascapes are large multiple-use marine areas, defined scientifically and strategically, in which government authorities, private organizations and other stakeholders cooperate to conserve the diversity and abundance of marine life and promote human wellbeing (Atkinson et al., 2011).

Beginning in the early 1990s, governance of fisheries and coastal resources has shifted in many countries in Southeast Asia from a centralized agency to decentralizing the responsibility and authority for the management of nearshore fisheries and coastal resources to the local government units (Pomeroy \& Viswanathan, 2003). Governance regimes, such as community-based management and co-management, emphasize stakeholder participation and empowerment in order to improve the effectiveness of resource management. In the Caribbean there has been a similar growing emphasis on governance but, due to the small size of the countries and weak local government arrangements, there has been less emphasis on decentralization and community-based management (Pomeroy et al., 2004). Instead, national co-management institutions and authority delegated to non-governmental organizations (NGOs), including fisherfolk bodies, are more prominent in stewardship.

Marine protected areas (MPAs) and networks of MPAs have increased in number as spatially defined areas whose purpose is to not only protect target species from exploitation in order to allow their populations to recover, but also to protect entire ecosystems by conserving multiple species and critical habitats. Interactions between MPAs and SSF provide some of the most compelling reasons for improving planning (Sissenwine et al., 2009).

All of the above approaches, developed under different disciplines and conceptual frameworks, are strategies to achieve the same thing: sustainable development. Sustainable development can be described as a process for finding a balance between ecological well-being and human well-being so that development does not destroy the natural resource base on which it is dependent but avoids overprotection of resources that prevents rational development (Hasna, 2007). A distinction can be made between these approaches however. Multi-sectoral approaches, such as EBM and ICM, deal with goals for sustainable development in a given region or ecosystem, including all sectors (e.g. fisheries, mining, shipping, tourism etc.). Sectoral approaches, such as EAFM, focus on managing a given sector (e.g. fisheries) in a way that is consistent with a wider ecosystem well-being focus. Both of these categories of approaches feature systems for monitoring social-ecological changes and learning to facilitate adaptation. The latter category may, however, permit SSF a greater place of prominence among the several competing and conflicting uses of marine space that are characterized by actors who are typically more powerful and capable than those in SSF.

\section{Marine Spatial Planning}

As discussed above, several approaches to managing large to small marine areas already exist including marine ecosystems, large marine ecosystems, seascapes, regional seas programs, and integrated coastal management (Bensted-Smith \& Kirkman, 2010). Another integrated approach, marine spatial planning, offers distinct cross-sectoral benefits in terms of accommodating multiple objectives and priorities (Ehler \& Douvere, 2009). So where does marine spatial planning fit into all of this?

Most coastal nations already allocate ocean space among different uses, such as concession zones for oil and gas development, delineation of shipping routes, and designation of areas for nature protection. The problem is that this allocation is most usually done on a single sector basis with no plan or policies for addressing conflict or compatibility and not necessarily addressing ecological considerations (Ehler, 2013). The application of marine spatial planning is growing rapidly around the world. Over the past decade MSP has been developed and implemented in over 20 countries worldwide and currently covers about $10 \%$ of the surface area of the world's exclusive economic zones (Ehler, 2013). 
MSP is “...the public process of analyzing and allocating the spatial and temporal distribution of human activities in marine areas to achieve ecological, economic and social goals and objectives that are usually specified through a political process." (Ehler \& Douvere, 2009). MSP is a way to improve on the sector-oriented management currently being used to move to a more comprehensive and coordinated approach to addressing the multiple and increasing conflicting uses of the sea. MSP is a planning process for sea/ocean use management. It does not directly address terrestrial issues. The principal output of MSP is a comprehensive spatial management plan for a marine area or ecosystem that can influence the spatial and temporal distribution of human activities. It should be noted that MSP is not merely ocean zoning. The comprehensive marine spatial plan is, however, usually implemented through a zoning map(s) and/or a permit system (Douvere, 2010; Ehler \& Douvere, 2009).

The characteristics of MSP (Ehler, 2013), many of which are common to other planning approaches including integrated coastal management and ecosystem-based management, are that it is:

- Integrated and multi-objective, across sectors and agencies, and among levels of government, and includes social and economic, as well as ecological, objectives

- Continuing and adaptive, capable of learning from experience

- Strategic and anticipatory, focused on the long-term

- Participatory, stakeholders actively and effectively involved in the process

- Place-based or area-based, focused on a specific marine area or place; and

- Ecosystem-based, balancing ecological, economic, and social goals and objectives toward sustainable development.

MSP is a planning process and can complement and link with other coastal, fisheries and ocean resource management plans developed through other approaches, such as ICM and integrated watershed management (IWM). For example, MSP, ICM and IWM are similar in that they are integrated, strategic, and participatory - and all aim to maximize compatibilities among human activities and reduce conflicts both among human uses and between human uses and nature. ICM has been limited in most countries to the coastline within a few kilometers of the shoreline and rarely includes inland watershed areas or extends into the territorial sea (Christie, 2005). MSP can link with ICM and IWM to integrate planning and management in the land/sea interface and to determine an efficient and effective allocation of land and ocean space. It can also be used to integrate across agencies and sectors with differing mandates on land and sea and to link terrestrial and ocean legislation that supports stewardship. Article 10 of the international Code of Conduct for Responsible Fisheries, for example, promotes the integration of fisheries into coastal area management (FAO, 1995). MSP should be seen as an approach to make key components of EBM of marine areas a reality. EAFM and MPAs, other approaches to implement EBM, link with MSP for integrated and comprehensive ocean management.

\section{MSP and fisheries management}

In many countries in Asia and the Caribbean, conventional fisheries management is transitioning to an ecosystem approach to fisheries (EAF) or fisheries management (EAFM). EAFM improves on conventional fisheries management approaches (Pomeroy et al., 2013). EAFM does so by considering not only fishing activities and the dynamics of targeted fish populations, but also competitors, predators, and prey; the quantity and quality of the habitat that supports each life-stage; cultural, societal, and economic importance; the effects of climate change and invasive species; and the dynamic interactions among these components. EAFM also considers interactions with other human uses such as energy, mineral extraction, coastal development, tourism, shipping, and national security to improve future management decisions. Essential for fisheries stewardship, it takes a SES perspective and is often collaborative adaptive management.

EAFM incorporates most aspects of conventional fisheries management and integrates many other existing approaches to marine and coastal resources management. EAFM can be considered a sectoral management approach, however, it focuses on fisheries management 
outcomes in a way that is consistent with a wider ecosystem well-being orientation (both natural and human). Sectoral approaches such as EAFM fit within broader multi-sectoral approaches, such as EBM and, to a lesser extent, integrated coastal management (ICM) and MSP, which deal with management goals across diverse sectors such as fisheries, mining, shipping, tourism, coastal development, agriculture, and forestry. In a sense, because fisheries remain central, it assists in scaling up SSF matters within a broader governance context without unduly diluting their importance as additional stakeholders and issues are considered.

MSP can provide essential information for the development of a plan for EAFM (Ehler, 2013). For example, spatial and temporal information on ecologically and biologically sensitive areas (EBSAs) is routinely collected and mapped for MSP during its analysis and planning phase. EBSAs would include: areas of high biodiversity, high endemism, and high productivity, as well as spawning areas, nursery areas, migration corridors and stopover points. These areas are often seasonal or limited to certain months. Since MSP usually has at least a 20 -year planning horizon, changes in the location or timing of EBSAs due to climate change are also identified when and if possible. In addition, the MSP planning process also includes collecting information and mapping existing and future human activities in the marine area within and around the EAFM area. If done in a planned participatory process, such information acquisition and management can simultaneously engage, empower and build capacity for stewardship in SSF. MSP supports management at the spatial, temporal, and governance scales appropriate for EAFM. Establishing and implementing an effective EAFM should be based on the spatial, temporal, and governance scales appropriate to achieve the prioritized goals and management objectives. These same considerations apply to MSP as well.

\section{Application of MSP in Asia and the Caribbean}

Marine spatial planning and marine zoning are being utilized to achieve different objectives in different environments throughout Asia and the Caribbean. Case studies on the application of MSP and marine zoning are presented below from selected locations (Figure 1).

\subsection{St Kitts and Nevis}

Located in the Leeward Islands, the Federation of St. Kitts and Nevis (SKN) comprises two volcanic islands with a large coastal shelf to land ratio. The goal of a recent one-year pilot project was to lay the groundwork for future implementation of marine zoning in SKN by assisting in the development of a marine zoning design and to provide a set of tools that could inform this and other management efforts (Agostini et al., 2010). Typical of many Caribbean SIDS, SKN is a "data poor" location and required collection of a range of spatial information on the multiple uses of the coastal and marine environment. A large effort was made to collect primary data including benthic and coastal habitats, reef health, relative valuation of fishing areas by fisher communities, tourism facilities and attributes, and shipping routes. This data along with information on the relative compatibility of marine resource uses were used in the 'Marxan' decision support tool for MSP (Ball \& Possingham, 2000). MARXAN is software designed to aid systematic reserve design on conservation planning. With the use of stochastic optimization routines, it generates spatial reserve systems that achieve particular biodiversity representation goals with reasonable optimality.

This marine zoning project was funded by USAID and implemented by The Nature Conservancy (TNC) using a participatory approach to engage stakeholders in both the data collection process and the development of the marine zoning design. The marine zoning process utilised a steering committee, comprising various government and other marine stakeholders, to establish clear objectives, participate in habitat surveys and expert mapping exercises to fill data gaps, receive training in the outputs of the Marxan decision support tool and utilize its' outputs in the generation of draft zones for SKN (Agostini et al., 2010). Since 2010, the zoning design output has been taken on by the Department of Marine Resources and used to drive the process to legally establish a marine management area that includes a region around the two islands out to the $30 \mathrm{~m}$ isobath 


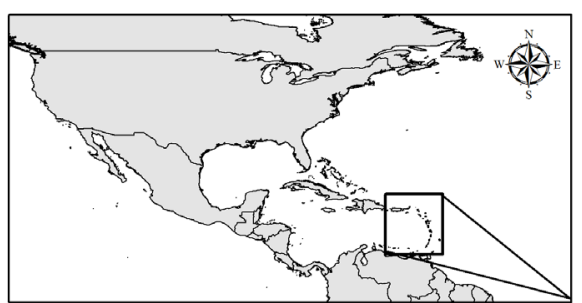

Caribbean

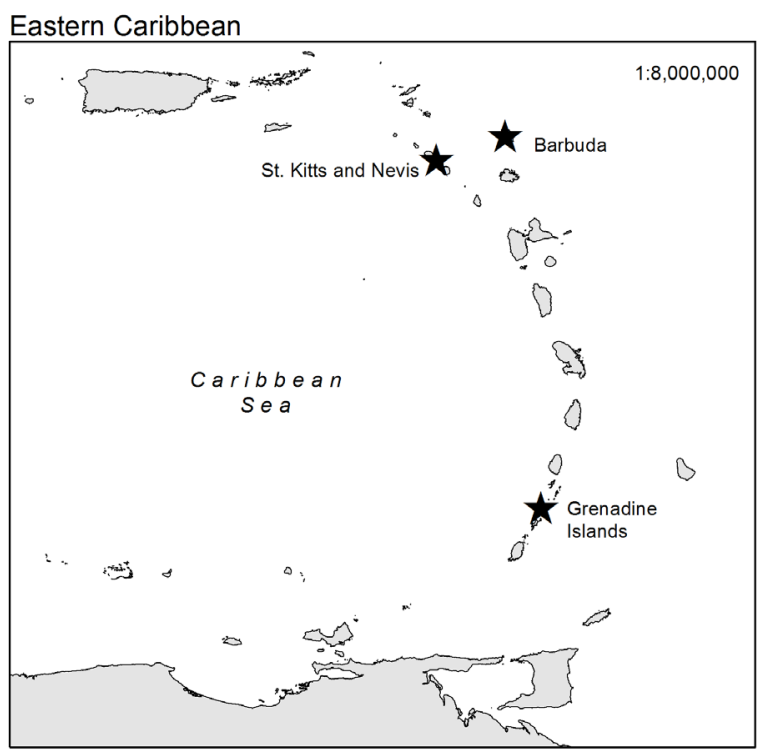

Asia
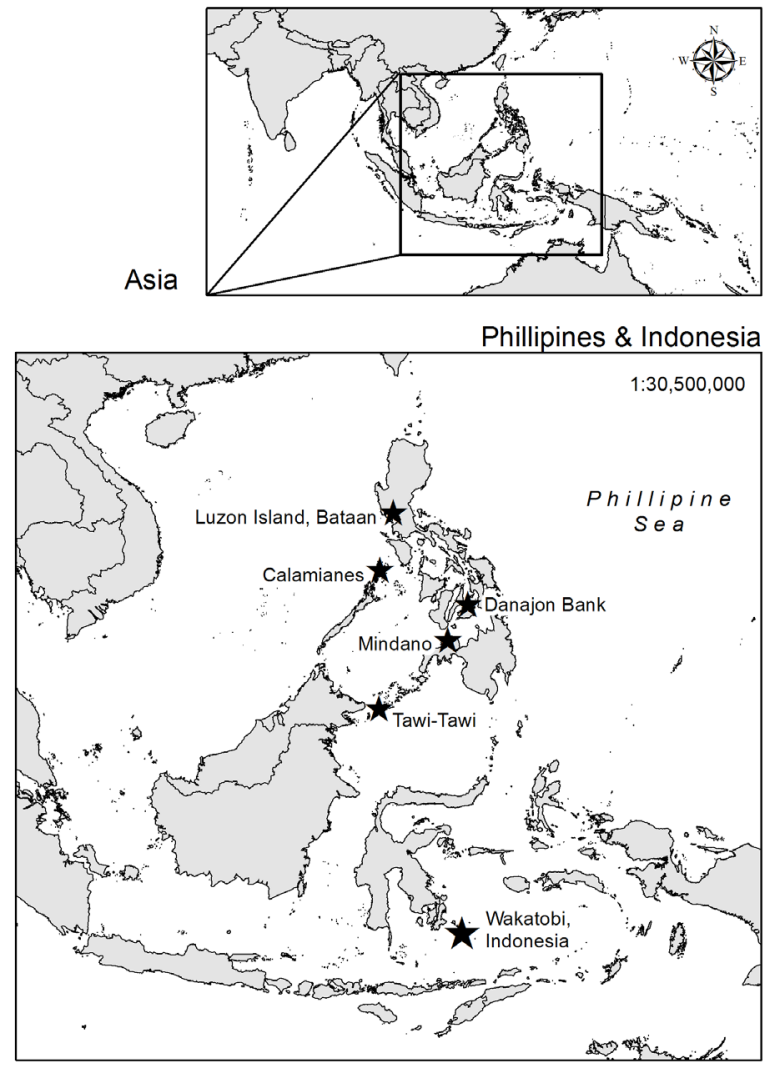

FIGURE 1 - Locations of selected MSP and marine zoning case studies from the Caribbean and Asia.

(R. Blyther, personal communication). In addition, the MSP is informing SKN's Draft National Maritime Policy and Action Plan (2013) led by the SKM Maritime Affairs and supported by the Commonwealth Secretariat. Moreover the lessons learned in the SKN MSP project were transferred to the Grenadine Islands MSP project (Baldwin, 2012a), which demonstrated the potential for replication.

Also, following up immediately on the first draft zoning plan, the SKN Department of Marine Resources (DMR, 2011) undertook a small grant project titled Preparing to introduce an ecosystem approach to fisheries in St Kitts and Nevis. In collaboration with the Centre for Resource Management and Environmental Studies (CERMES), Organisation of Eastern Caribbean States (OECS) and Caribbean Regional Fisheries Mechanism
(CRFM) the Department of Marine Resources used the zoning plan as the basis for consultations with fisheries stakeholders on the introduction of EAF. The consultations asked the following:

- What the ecosystem approach to fisheries in St Kitts and Nevis would look like (general visioning)

- What help the fisheries authority and fishing industry needs to start EAF (capacity development)

- Where would starting points on this path be that are most likely to succeed (key EAF entry points).

Fisherfolk, environmental NGOs and recreational marine space users had different but overlapping visions, perspectives and recommendations. What stood out 
was the need to balance economic and environmental interests so that all stakeholders would play their part in stewardship given low technical capacity. The implementation of EAF should start with small incremental steps, to try and test and learn by doing. There was strong support for monitoring, evaluation and adaptation at the local level prior to scaling-up (DMR, 2011).

\subsection{The transboundary Grenadine Islands}

Located in the Eastern Caribbean, the Grenadine Islands lie atop the transboundary Grenada Bank and are shared by the SIDS of Saint Vincent and the Grenadines and Grenada. From 2006-2010, an academic-NGO partnership was used to implement a participatory geographical information system (PGIS) approach as a conceptual framework to integrate conventional biophysical and management information with information derived from the practical knowledge of marine resource users (Baldwin, 2012b). The resulting Grenadines Marine Resource and Space-use Information System (MarSIS) provides an integrated baseline of the extent and distribution of marine resources, associated patterns of use and the identification of threats for use in planning ecosystembased management (Baldwin \& Mahon, 2014). From 2010-2012, funding was granted to Sustainable Grenadines Inc. from the National Oceanic and Atmospheric Administration (NOAA), Global Environment Fund Small Grants Program (GEF-SGP) and technical support and guidance was provided by TNC to utilize the MarSIS as the foundation for a marine multi-use zoning exercise for the Grenadine Islands (Baldwin, 2012a). Similar to the development of the MarSIS, the zoning process applied a cross-scale participatory approach to engage stakeholders in the development of a shared vision and objectives, determination of space-use zones and the evaluation of trade-offs to draft a transboundary multiuse zoning plan to guide the sustainable development of the Grenada Bank marine resources. As with SKN, this MSP process utilized the 'Marxan with Zones' decision support tool to allow stakeholders to explore compatibility amongst uses, evaluate trade-offs and assist with the development of an ecosystem based zoning design for the Grenadine Islands.

In this transboundary SIDS case, there is a mismatch between the existing jurisdictional (legal-institutional) scale and the geographical (social-ecological) scale of the Grenada Bank. The academic-NGO partnership had to work between and within the existing national institutional frameworks of the two countries, as well as to bridge the various levels of stakeholders across the geographic scale of the transboundary island chain (Baldwin et al., 2013). Although the MarSIS has been actively used by a variety of stakeholders since its public release (Baldwin et al., 2013), inadequate sub-regional governance mechanisms have precluded the implementation of the marine zoning plan by either country.

Despite this, the Grenadines MSP work has been used to inform the draft St. Vincent and the Grenadines National Ocean Policy and Action Plan implemented by the Maritime Administration and funded by the European Union (SVGMARAD, 2013). More recently, through the revision of the St. Vincent and the Grenadines National Biodiversity Strategy and Action Plan funded by United Nations Environment Program (UNEP), a pilot project to inventory and assess the coastal and marine resources and space-use patterns of the South Coast of St. Vincent was undertaken. This information will be used to develop a marine multi-use zoning design for the proposed South Coast Marine Park (Baldwin, 2014).

Concerning SSF specifically in the same period, Sustainable Grenadines Inc. also had a small grant from the Centre for Resource Management and Environmental Studies (CERMES) to "establish a fishers group, through which fisher folk collaboration in the Grenadines could be strengthened at a multi-island, transboundary scale, to address shared fisheries issues" (SusGren, 2010). Although the fishers shared interests with the other marine users, consultations revealed that any fisher group would need to be an island-based social network with northern, central and southern Grenadines clusters. If this network structure, which did not coincide with legal or ecological boundaries, was not taken into account there could be challenges with effectively engaging fishers in ecosystem stewardship as part of MSP for ocean management or biodiversity. 


\subsection{Barbuda Blue Halo Initiative, Antigua and Barbuda}

Barbuda is a small island in the Eastern Caribbean that forms part of the nation-state of Antigua and Barbuda. From 2013-2014 a MSP project called the Blue Halo Initiative, supported by the Waitt Institute, was undertaken to aid the sustainable management of the coastal waters of Barbuda (one league or $5.55 \mathrm{~km}$ offshore). The MSP process collected a range of ecosystem-based information and utilized a highly participatory approach to develop a vision, objectives and planning principles for a marine zoning design that would minimize the negative impacts to fishing and coastal livelihoods (Waitt, 2013). Habitat mapping, ecological assessments, surveys, community consultations and the decision support tool 'SeaSketch' were applied to allow a range of stakeholders participate in the demarcation, evaluation and discussion of various zoning scenarios (www.seasketch.org). As a result, a draft zoning design and coastal zoning and fisheries legislations, as well as an ecological assessment, legal analysis, sustainable coastal policy and a number of ecological and community datasets were produced (Waitt, 2013).

\subsection{FISH Project in the Philippines}

The seven-year Fisheries Improved for Sustainable Harvest (FISH) project (2003-2010) provided technical assistance and training to coastal communities, local government units (LGUs), non-governmental organizations (NGOs) and assisting national government agencies to promote sustainable fisheries in four critical marine ecosystems in the Philippines: the Calamianes Group of Islands in northern Palawan; Danajon Bank in Central Visaysas; Mindanao's Sulu Archipelago with particular focus on Tawi-Tawi; and Mindano's Pacific seaboard in Surigao del Sur. The project was funded by USAID and implemented by Philippine national government agencies, local government units, NGOs and people's organizations (FISH, 2010).

The project encouraged LGUs to work together in sorting out common resource uses and conflicts in their municipal waters through fisheries zoning. The LGUs were supported in the delineation of municipal waters to identify boundaries. Zoning primarily involved marine spatial planning focused on fishery resource use within defined ecosystems shared by the different LGUs in the focal areas. It was intended primarily to determine and evaluate the interactions among the various uses, identify multiple uses and resolve any exiting or potential conflicts through proper allocation of space. The zoning process was participatory and included orientation training, fisheries mapping, and consultations with local stakeholders to determine and propose solutions to existing or potential use conflicts. The zoning plans, as well as ecosystem models developed by the project for each of the focal areas, fisheries registration data and other information collected from the implementation of various management interventions, fed into the preparation of the fisheries management framework plan.

\subsection{Bataan, Philippines}

Bataan is located in the southwestern part of Luzon Island on the northern shore of Manila Bay. A spatial planning and zoning plan was prepared to address five major problems in the area including pollution from land- and sea-based activity, illegal and destructive fishing methods, siltation and sedimentation, proliferation of informal settlers, and habitat destruction. There were also multiple use conflicts between shipping and ports and fisheries and aquaculture, reclamation of coastal habitats, and land development in agriculture and fishpond areas. The Coastal Land- and Sea-use Zoning Plan (CLSUZP) was developed to define the uses of the different zones in the Bataan Coastal Area and municipal waters and to help in resolving resource-use conflicts in the province (Bataan Coastal Care Foundation, 2007).

The integrated zoning plan was developed by an interagency and multisectoral group from the province. The plan was adopted on 4 December 2006 by the Bataan Provincial Board through Sanggunian Panlalawigan 155 (Provincial Order 155). The zones were classified and designated based on the level of development, utilization and/or resources in the area. The CLSUZP is one of the integral components of the Bataan Integrated Coastal Management Program in ensuring the sustainable development of Bataan. 


\subsection{Wakatobi National Park, Indonesia}

Wakatobi National Park is located in Southeast Sulawesi, Indonesia. Four main islands of Wangi-Wangi, Kaledupa, Tomia, and Binongko, together with several small islands comprise the Tukang Besi Archipelago at the southeastern tip of Sulawesi, Indonesia - this area is known as Wakatobi. In 2003, a Rapid Ecological Assessment of Wakatobi was conducted which revealed widespread coral damage, primarily from fishing pressures, and minimal coral bleaching (The Nature Conservancy, 2008). The immediate threats to Wakatobi National Park result from destructive fishing practices (blast fishing, cyanide) and overfishing. In addition, coastal development threatens the coral reef and coastal environment of the area (http://www.reefresilience.org/Toolkit_Coral/ C8_Wakatobi.html; accessed 30 March 2010)

To address overfishing and destructive fishing practices in Wakatobi, NGOs have been working with the Wakatobi National Park Authority and a broad range of stakeholders to redesign the Park's management plan. The process involves focusing on collaborative management and building firm legal foundation for Park zoning and enforcement. The goal of the management plan is to support the establishment of effectively managed MPA sites as foundations for resilient networks of functionally connected MPAs.

MPA network management, planning and design have occurred through the alignment of district spatial planning (District Management Plan) and national Park zoning (Wakatobi National Park Management Plan). Extensive technical team trainings and meetings with partners enabled zoning revisions of the MPA network and management planning. Resilience principles (in particular, representation, replication, and critical areas) have been incorporated into the initial rezoning and spatial planning for Wakatobi, through use of the 'Marxan' decision support tool.

The 'Marxan' planning process developed scenarios for the zoning design of Wakatobi, based upon biological, ecological, and socioeconomic features of the area. Communication and local community input and perspectives were also incorporated into the final MPA planning and design. In 2007, the Director General of
Forest Protection and Nature Conservation of the Ministry of Forestry and the Head of the Wakatobi District formally signed the Wakatobi National Park's Zoning System. The Wakatobi zoning systems comprises: a core zone of no-take and no-entry, marine zone of no-take, a tourism zone of no-take, allowed only for tourism activities, and a traditional use zone dedicated for pelagic fisheries. As a result of the planning process, Wakatobi National Park has been able to more effectively manage the area, in alignment with the district spatial planning.

\section{Implications for MSP in Asia and the Caribbean}

As a result of the case studies on the application of MSP in Asia and the Caribbean, it was found that:

- need for stakeholder input through awareness raising and forums with the local community

- ensure that the objective is supported by local community and government

- working with the government was essential to encourage and advance a shared management regime

- to manage effectively, coastal managers have to focus on the objective and look beyond one's area and sector of jurisdiction to multi-sectoral cooperation

- there must be strong political will to back management and enforcement actions

- there is a need to have a strategic long-term roadmap and objectives for the sustainable development of the area

- MSP must take into account land-sea interactions

- need to integrate a diverse set of information; doing so in "data poor" systems requires application of innovative tools with a strong focus on participatory approaches

- prioritizing the link between science and policy

- take into account formal and informal networks of information, other resource flows and power

- pay attention to scale mis-matches particularly in transboundary arrangements by examining several levels in the social-ecological systems 
- stakeholders often seek incremental, learning by doing approaches to change that appear to minimize risk and maximize the potential for adaptation, especially when livelihoods and well-being are at stake

There are a number of positive aspects of MSP and ocean zoning which can support improved ocean and small-scale fisheries management in Asia and the Caribbean. As a resource management approach, MSP and ocean zoning can clarify use and, in some cases, property rights in the marine environment. Ocean zoning can establish clear rights and responsibilities which can reassure resource users and businesses about long term investments in marine resources (East Asian Seas Congress, 2009).

There are also challenges to MSP implementation. The capacity to implement MSP and ocean zoning comprehensively is largely lacking throughout both regions. This is a new paradigm and much more awareness raising and technical expertise is needed. Whether resources will be put into MSP over other paradigms will depend upon the need and purpose for resource management.

Haughton \& Mutrie (2011) state that in the Caribbean region much more work is needed to promote MSP and test its suitability in the region. The major challenges may not be intrinsic to MSP as a tool per se, but rather the complex ecological and geo-political characteristics of the region and lack of political will. There are also limitations in the existing governance frameworks and limitations in basic data and information needed to apply MSP (Baldwin \& Mahon, 2014). The levels of interest and perceptions of stakeholders regarding conservation and resource management generally and the usefulness of MSP in particular, are linked to limitations in the human, institutional and financial resources needed to develop and sustain its application. Yet the Caribbean cases illustrate potential even in complex circumstances.

Agostini (2011), reported on marine zoning at three tropical sites: Raja Ampat (Indonesia), Samana Bay (Dominican Republic) and Saint Kitts and Nevis (Caribbean), identified a number of common challenges. These include: collecting and integrating information that truly addresses multiple objectives; maintaining a dynamic information base; representing future growth (and climate change); addressing scale issues (e.g. coastal versus offshore, biodiversity versus use information); facilitating stakeholder participation in a multi-use world; implementing functional governance mechanisms. Agostini (2011) also noted as with a number of other marine zoning efforts around the world the remaining challenge is moving beyond the planning phase to the implementation phase.

Most of the cases of MSP and zoning are undertaken with outside project funds not national or local funding. While this is an important method to introduce a new paradigm, it is always a concern for sustainability. Rather than being imposed from outside, MSP should be allowed to take on different forms in different contexts. In St. Vincent for example, although the transboundary zoning design has not yet been implemented, the process of participation in this exercise has clearly built understanding in the value of MSP and subsequent MSP initiatives have been undertaken as a result (SVGMARAD, 2013; Baldwin, 2014). MSP can only be successful if it meets a clearly defined need and purpose and a stated demand(s).Most likely, these demands will stem from conflicts arising from the multiple uses of resources and the lack of an integrative perspective. The needs-based approach is closely linked to the issue of scale and appropriateness of response. If conflicts are small-scale and local, it may be sufficient to establish a forum for dialogue and exchange rather than a national or even international system of MSP.

The costs of doing MSP may differ depending upon the detail of analysis undertaken and desired. If, for example, the process suggested by Ehler \& Douvere (2009) is followed, the costs can be quite high. But a marine spatial plan could also be undertaken using participatory assessment tools. For example, in the development of the MarSIS, used in the Grenadine Islands MSP, over $60 \%$ of the data were based on the 'tacit' knowledge of resource users (Baldwin, 2012b). Although the application of a PGIS approach is time consuming, it was found to have relatively low cost compared to other MSP initiatives as well as to strengthen cross-scale marine governance (Baldwin et al., 2013). Moreover a plan could be developed with some sheets of paper and colored markers and a group of key informants and then presented to the larger stakeholder community for comment.

As a new paradigm, there are inconsistencies or lack of local and national policies and laws to support 
MSP. There is a need to develop new laws and policies and institutional structures to support MSP. MSP will need to take into account the political realities of introducing a new resource management paradigm into an already full field of paradigms. MSP will need to be shown to be better than or complement existing paradigms in order to receive support and resources.

MSP on its own is not superior, to other approaches for capturing the elements of social-ecological change in SSF. A largely context-driven combination of integrated approaches is likely to be most useful. However the data and information in the monitoring component of MSP are invaluable for SSF, especially in EAF or EAFM. The most challenging linkage, however, is stewardship. MSP is clearly compatible with a regulatory system of enforcement, but does not necessarily promote compliance and stewardship. The participatory processes embedded within MSP (Ehler \& Douvere, 2009) can be conducive to stewardship but more focused attention may be required.

\section{Conclusions}

The countries of the Asia and Caribbean regions are at different stages of MSP and marine zoning development and implementation. While MSP and zoning is increasingly recognized as an important management approach for ocean resources, countries in the regions are still challenged by various capacity, technical, legal, and institutional concerns in the implementation process. In addition, enforcement and policy support are challenges faced by some countries which have already begun to utilize MSP and zoning. These approaches can only be effective if governments are able to provide the necessary legal mechanisms at the national and local levels to enforce and implement regulations and policies. There is also a need to have governance mechanisms for inter-agency, multi-sectoral and transboundary decisionmaking and coordination. Most MSP initiatives are still less than 10 years old and time will demonstrate how successful they will be. Pilot projects are needed to adapt MSP to local circumstances and demonstrate and document its practical benefits to policy-makers and other stakeholders at various scales.
There are a range of approaches available for ocean use management. Some, such as conventional fisheries management and ICM, have been around for decades, while others, such as EAF and EAFM are relatively new. There is confusion among fisheries and coastal managers about which paradigm should be used in what situation. MSP is only one tool of ocean use management. It holds promise for addressing many of the conflicts which exist in the coastal and ocean waters of Asia and the Caribbean. MSP and its implementation should be closely linked with other resource management paradigms, especially fisheries management (whether conventional or EAFM) and integrated coastal zone management. Applications of MSP will be a mix of approaches including zoning, other management measures, and regulatory or economic incentives; planning processes will probably be a mix of "bottom up" and "top down", depending on the culture and political process; planning for MPA networks should be an integral part of MSP. The future use of MSP in the regions will depend on raising awareness of the approach and showing its effectiveness. Cost will also play a significant role.

A number of management and capacity development actions could move MSP forward in both regions:

- Engage stakeholders in a dialogue on conservation and management of living marine resources, especially those that are shared.

- Build capacity for MSP. Little if any capacity for MSP currently exists outside a few organizations. An investment in MSP training across the regions could have long-term benefits, especially when it builds on the successes of established programs.

- Establish governance structures that integrate coastal and marine management to provide robust protection of both in the face of climate change, unsustainable fishing and marine pollution.

- Pursue the establishment of integrated coastal and marine management, including MSP, across both the regions to reverse the decline of the health of coastal and marine ecosystems.

- Develop and/or strengthen stakeholder and community engagement processes at the local, national and regional levels. 


\section{References}

Agostini, V. Marine zoning in the water: lessons from the field In: McConney, P.; Chuenpagdee, R. (Eds.). Report of session on Marine spatial planning in small islands and other developing States: practices and prospects. 16 May 2011 at the 2nd International Marine Conservation Congress, Victoria, British Columbia, Canada. CERMES Technical Report No. 46, 2011. p. 5-6.

Agostini, V.; Margles, S.; Schill, R.; Knowles, J.; Blyther, R. Marine zoning in Saint Kitts and Nevis: A path towards sustainable management of marine resources. St. Criox, USVI: The Nature Conservancy, 2010.

Atkinson, S.; Esters, N.; Farmer, G.; Lawrence, K.; McGilvray, F. The Seascapes Guidebook: How to Select, Develop and Implement Seascapes. Arlington, VA: Conservation International, 2011. Available at: http://www.coraltriangleinitiative.org/ library/guidebook-seascapes-guidebook-how-select-develop-and-implementseascapes-october-2011

Baldwin, K. Developing a framework for a comprehensive marine multi-use zoning plan for the Grenadine Islands. For the Sustainable Grenadines, Inc., Union Island, St. Vincent and the Grenadines, 2012a. Available at: http://www.grenadinesmarsis. com/Files_and_Maps.html.

Baldwin, K. A Participatory Marine Resource \& Space-use Information System for the Grenadine Islands: An ecosystem approach to collaborative planning for management of transboundary marine resources. Barbados, $\mathrm{PhD}$ Dissertation, University of the West Indies, 2012b.

Baldwin, K. Training exercise and rapid assessment of the proposed South Coast Marine Park, St. Vincent, St. Vincent and the Grenadines. For the Ministry of Health, Wellness and the Environment,The Revision of the National Biodiversity Strategy and Action Plan and the development of the Fifth National Report to the Convention on Biological Diversity, Kingstown, St. Vincent, 2014.

Baldwin, K.; Mahon, R. A geospatial framework to support marine spatial planning and management for the transboundary Grenadine Islands. Electronic Journal of Information Systems for Developing Countries, 63, 7, 2014.

Baldwin, K.; Mahon, R.; McConney, P. Participatory GIS for strengthening transboundary marine governance in SIDS. Natural Resources Forum, 37(4), 257-268, 2013.

Ball, I. R.; Possingham, H. P. Marxan (v. 1.8.6): Marine Reserve Design Using Spatially Explicit Annealing. User Manual: http://www.uq.edu.au/marxan. 2000.
Bataan Coastal Care Foundation. The coastal land- and sea-use zoning plan for the Province of Bataan. Partnerships in Environmental Management for the Seas of East Asia (PEMSEA). Quezon City, Philippines, 2007.

Bensted-Smith, R.; Kirkman, H. Comparison of Approaches to Management of Large Marine Areas. Cambridge, UK: Fauna \& Flora International and Washington, USA: Conservation International, 2010. Available at: http://www.fauna-flora.org/ docs/Management-of-Large-Marine-Areas.pdf

CEMARE. The management of conflict in small-scale fisheries. University of Portsmouth, UK. 61p., 2002.

Christie, P. Is integrated coastal management sustainable? Ocean and Coastal Management, 48, 208-232, 2005.

Christie, P.; Fluharty, D. L.; White, A. T.; Eisma-Osorio, R. L.; Jatulan, W. Assessing the feasibility of ecosystem-based fisheries management in tropical contexts. Marine Policy, 31, 239-250, 2007.

Cincin-Sain, B.; Knecht, R. W. Integrated Coastal and Ocean Management: Concept and Practices. Island Press, Washington, D.C. $571 \mathrm{p} ., 1998$.

CRC - Coastal Resources Center. Fisheries Opportunities Assessment. University of Rhode Island, and Florida International University. 104p., 2006.

DMR - Department of Marine Resources. Preparing to introduce an ecosystem approach to fisheries in St Kitts and Nevis: the final meeting. Report of the DMR produced under a CERMES MarGov Small Grant. 18pp., 2011.

Douvere, F. Marine spatial planning: concepts, current practices and linkages to other management approaches. Ghent University, Belgium, 2010.

Eagle, J. Regional ocean governance: the perils of multiple-use management and the promise of agency diversity. Duke Environmental Law and Policy Forum, 16, 143-177, 2006.

East Asian Seas Congress. Theme 1: Coastal and ocean governance; Workshop 6: land and sea use zoning: challenges and opportunities. In: The East Asian Seas Congress 2009 Proceedings, Manila, Philippines, 23-27 November, 2009.

Ehler, C. Coral Triangle Initiative: An introduction to marine spatial planning. Jakarta, Indonesia: Coral Triangle Initiative on Coral Reefs, Fisheries and Food Security, 2013.

Ehler, C.; Douvere, F. Marine Spatial Planning: a step-by-step approach toward ecosystem-based management. Intergovern- 
mental Oceanographic Commission and Man and the Biosphere Programme. Paris: UNESCO, IOC Manual and Guides No. 53, ICAM Dossier No. 6, 2009.

Fanning, L.; Mahon, R.; McConney, P. (Eds). Towards marine Ecosystem-Based Management in the Wider Caribbean. Netherlands: Amsterdam University Press, 2011.

FAO. Code of Conduct for Responsible Fisheries. Food and Agriculture Organization of the United Nations (FAO), Rome, 1995.

FISH - Fisheries Improved for Sustainable Harvest. 7 years and 4 seas: Our quest for sustainable fisheries. A special end-of-project report to partners on the implementation of the Fisheries Improved for Sustainable Harvest (FISH) project in Coron Bay, Danajon Bank, Lanuza Bay and Tawi-Tawi, Philippines, 2003-2010. Cebu City, Philippines: FISH, 2010.

Hasna, A. M. Dimensions of sustainability. Journal of Engineering for Sustainable Development: Energy, Environment, and Health, 2(1), 47-57, 2007.

Haughton, M.; Mutrie, E. The challenges of MSP in the governance of living marine resources in the Caribbean. In: McConney, P.; Chuenpagdee, R. (Eds.). Report of session on Marine spatial planning in small islands and other developing States: practices and prospects. 16 May 2011 at the 2nd International Marine Conservation Congress, Victoria, British Columbia, Canada. CERMES Technical Report No. 46, 2011, p. 4-5.

Heathcote, I. W. Integrated watershed management: principle and practice. 2009. Wiley.

Mahon, R.; Fanning, L.; McConney, P.; Pollnac, R. Governance characteristics of large marine ecosystems. Marine Policy, 34, 919-927, 2010.

Pomeroy, R. Marine Spatial Planning in Asia: Application and Implications. In: McConney, P.; Chuenpagdee, R. (Eds.) Report of session on marine spatial planning in small islands and other developing states: practices and prospects. 16 May 2011 at the 2nd International Marine Conservation Congress, Victoria, British Columbia, Canada. CERMES Technical Report No. 46, 2011. p. 6-7.

Pomeroy, R.; Brainard, R.; Heenan, A.; Moews, M.; Shackeroff, J.; Armada, N. Coral Triangle Regional Ecosystem Approach to Fisheries Management (EAFM) Guidelines. Honolulu, HI: USAID Coral Triangle Support Partnership, 2013. Available at: http:/www.coraltriangleinitiative.org/sites/default/files/ resources/Guidelines_int_NEW_finalproof2.pdf

Pomeroy, R.; McConney, P.; Mahon, R. Comparative analysis of coastal resource co-management in the Caribbean. Ocean and Coastal Management, 47, 429-447, 2004.
Pomeroy, R.; Parks, J.; Pollnac, R.; Campson, T.; Genio, E.; Marlessy, C.; Holle, E.; Pido, M.; Nissapa, A.; Boromthanarat, S.; Thu Hue, N. Fish Wars: Conflict and Collaboration in Fisheries Management in Southeast Asia. Marine Policy, 31(6), 645-656, 2007.

Pomeroy, R.S; Viswanathan, K. Fisheries Co-management Developments in Southeast Asia and Bangladesh. In: Wilson, D. G.; Raakjaer-Nielsen, J.; Degnbol, P. (Eds.) The Fisheries Co-management Experience: Accomplishments, Challenges and Prospects. Dordrecht, The Netherlands: Kluwer Academic Publishers, 2003.

Sherman, K.; Hempel, G. (Eds). The UNEP large marine ecosystems report: a perspective on changing conditions in LMEs of the world's regional seas. UNEP Regional Seas Report and Studies No. 182. United Nations Environment Program. Nairobi, Kenya., 2009.

Sissenwine, M.; Pomeroy, R.; Sanders, J. Technical Guidelines for Marine Protected Areas as a Fishery Management Tool. FAO Technical Guidelines for Responsible Fisheries. UN Food and Agriculture Organization, Rome, 2009.

SusGren - Sustainable Grenadines Inc. Report on Strengthening Fisher Folk Collaboration in the Grenadines Project. SusGren, Centre for Resource Management and Environmental Studies CERMES, University of the West Indies, Cave Hill Campus, Barbados, 41 pp., 2010.

SVGMARAD - St. Vincent and the Grenadines Maritime Administration. St. Vincent and the Grenadines development of a national ocean policy: Discussion document. Kingstown, St. Vincent: SVGMARAD, 2013.

The Nature Conservancy. Wakatobi National Park, Wakatobi Government and World Wildlife Fund. Wakatobi National Park management and zoning system. Presentation for the Wakatobi National Park Management and Zoning Workshop. Wakatobi, Indonesia, 2008.

UNEP. Taking steps toward marine and coastal ecosystembased management - an introductory guide. United Nations Environment Program Regional Seas Reports and Studies No. 189. Nairobi, 2011. www.unep.org/ecosystemmanagement

Waitt Foundation. Barbuda Blue Halo Initiative: Description and workplan. Waitt, 2013. Available at: http://barbuda.waittinstitute.org/wp-content/uploads/2013/10/Detailed-Workplan.pdf

World Bank. Integrated river basin management. Washington DC. 20p., 2006.

WorldFish Center. Aquaculture, fisheries, poverty and food security. WorldFish Center Working Paper 2011-65. Penang, Malaysia, 2011. 